
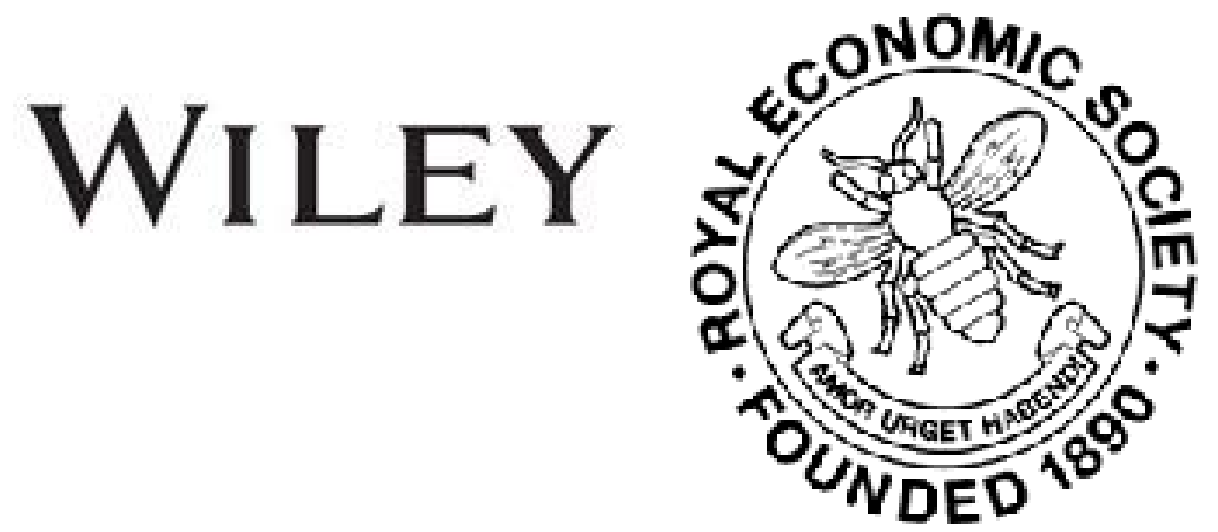

Pure Theory and the Fiscal Controversy

Author(s): A. C. Pigou

Source: The Economic Journal, Vol. 14, No. 53 (Mar., 1904), pp. 29-33

Published by: Wiley on behalf of the Royal Economic Society

Stable URL: http://www.jstor.org/stable/2220736

Accessed: 26-06-2016 20:49 UTC

Your use of the JSTOR archive indicates your acceptance of the Terms \& Conditions of Use, available at

http://about.jstor.org/terms

JSTOR is a not-for-profit service that helps scholars, researchers, and students discover, use, and build upon a wide range of content in a trusted digital archive. We use information technology and tools to increase productivity and facilitate new forms of scholarship. For more information about JSTOR, please contact support@jstor.org.

Wiley, Royal Economic Society are collaborating with JSTOR to digitize, preserve and extend access to The Economic Journal 


\section{PURE THEORY AND THE FISCAL CONTROVERSY}

Is much that has been written upon the fiscal controversy assertions have been made, the foundations of which rest upon certain positions of pure theory. Though, therefore, it may well be doubted whether any bridge between the abstract and the concrete can be built secure enough to warrant the passage of a positive solution, there can be no doubt of the great value of rigid analysis as a criterion of the positive arguments used by other people. It is from this point of view that the following solutions are offered of six abstract problems which bear indirectly upon the practical issue before the country. The solutions depend upon algebraic reasoning, and are not carried beyond the stage of first approximations.

Problem 1.-To determine the relation between the effect of a differential and that of a non-differential tax upon prices in the taxing country. It can be proved that, when the conditions of stable equilibrium are present, either kind of tax must in general raise the price to some extent. The problem is complicated in the case of increasing return, and we get the curious result that, when the taxed supply obeys the law of increasing, and the untaxed that of diminishing, return, the price may fall, even from a stable equilibrium point, as a direct consequence of the tax. The emergence of this paradoxical result (due, of course, to the suppression of the element of time when a plane curve is used to represent organic changes) suggests the necessity of extreme caution in extending the argument into so difficult a region. In treating of diminishing return we are upon surer ground, and may say definitely that a tax, whether upon one or upon both sources, necessarily raises the price, and that the price-change bears a larger proportion to the tax in the latter case than in the former. Furthermore, an obvious extension of the algebra shows that the rise of price caused by the conversion of a differential 
tax at the rate $T$ into a universal tax at the same rate is slightly less when the tax is rated ad valorem than when it is specific. Finally, it appears that the amount by which such a conversion tends to raise the price is greater, the greater, with given elasticities, is the quantity, and, with given quantities, is the elasticity of the untaxed relatively to that of the taxed supply; ${ }^{1}$ and less, the greater is the elasticity of the home demand. If the demand is constant and the elasticities of the two supplies equal, then the conversion will raise the price by a proportion of the tax represented by the originally untaxed supply divided by the total supply.

Problem 2.-To ascertain the effect upon price of taxing the supply from one source and expending the proceeds in a bounty upon that from the other, when both supplies obey the law of diminishing return. If the elasticities of the two supplies are the same, the price necessarily rises. If the elasticity of the taxed supply is the smaller of the two, it may fall. In any event it will rise less than it would do if the proceeds of the tax were not expended in a bounty.

After the maximum revenue point has been passed, any rise in the rate of the tax involves a diminution in the receipts from it, and therefore in the fund available for a bounty. Hence, after this point, the bigger the tax the greater the rise in price, even though the proceeds are devoted to a bounty.

Problem 3.-To ascertain the effect of commuting a given small tax $T_{2}$ yielding a revenue $R$ from two sources of supply into a tax $T_{1}$ so assessed as to yield the same revenue from one source of supply only.

Under the conditions of diminishing return, the consumers will always contribute a smaller proportion of the revenue raised by the tax when it is levied from one source only. But, on the other hand, they will have, in addition, to make a payment to the controllers of the untaxed source of supply, whether these reside within or without the taxing country. ${ }^{2}$ This element of

1 The term "elasticity of supply" is applied in this article to the supply offered in the market of the taxing country, and is to be distinguished from the elasticity of the total production in any source of supply. If the whole of that production were supplied to the taxing country, there would, of course, be no distinction between these two things. When, however, as in the case of wheat, only a portion of the foreign production is sold in England, these two elasticities are not only distinct, but may be widely divergent, from one another. $C f$. on this and other points "The known and the unknown in Mr. Chamberlain's policy," by the writer, in the Fortnightly Review for January, 1904.

2 If they reside outside, this extra payment is a total, if inside, only a partial loss to the taxing country considered as a whole. 
disadvantage may be either greater or less than the element of advantage just described. There is bound to be a loss on the whole if the ratio of the square of the supply offered from the untaxed source to the square of that from the taxed source is greater than the ratio of the elasticity of the untaxed to that of the taxed supply. When the elasticities are equal, there may be a gain if the quantity of the taxed exceeds that of the untaxed supply.

For complete analysis it is necessary further to distinguish the effect upon consumers' surplus of the two foregoing methods of raising the given revenue. If the demand is constant, this is not affected by a change from the one to the other. If the demand is not constant, it is necessary to determine under which method the price will be affected most. The rise of price will be greater when one source only is taxed if the supply from this source is more elastic than that from the other. Under these circumstances, there has to be added to the debit side of the account a certain loss of consumers' surplus. On the other hand, if the taxed supply is the less elastic of the two, a consideration of consumers' surplus strengthens the case for collecting the revenue from that source only, and continuing to leave the other untaxed.

Problem 4.-To ascertain the effect of most-favoured nation agreements upon the advantage which this country might expect to obtain from successful bargaining for the reduction of the French tariff. In general, the fact of concessions made to us having to be made to our rivals also, diminishes the benefit we receive from them. The extent to which it does this is greater the less elastic is the French demand for the goods in question, and the greater the quantity and the higher the elasticity of our rival's supply of them relatively to our own in the French market.

Problem 5.-A protective tariff is said to encourage the formation of Trusts. One party asserts that these necessarily raise prices to the injury of the consumer, and the other replies that they introduce economies, and therefore lower prices. Problem : to resolve this controversy. If a commodity, formerly produced under free competition, is taken over by a monopolistic corporation acting exclusively in its own immediate interest, prices may be either raised or lowered according to the extent of the economies which the combined management makes possible. In the simplest case, when the equations of supply and demand are assumed to be linear, in order to a lowering of price, the 
economies introduced must be so great that, had free competition continued, the amount of the commodity consumed would have been doubled in consequence of the change. These large economies are hardly possible except in industries which are being badly managed. As Mr. Bolen observes: "Such industries Trust promoters seldom choose. They naturally prefer those industries having already a monopolistic excellence that will float watered stocks." 1

Problem 6.-It is generally admitted that the power of resorting to various kinds of dumping is a factor in "commercial " competition. Problem : to ascertain how far it is also a factor in industrial competition, how far, that is to say, the anticipation of it will attract capital towards businesses in which it is practicable.

The case of dumping with a view to destroying foreign rivals is not here considered. The questions raised relate $(a)$ to sales abroad, regularly made at lower prices than at home; $(b)$ to the dumping of surplus produce.

(a) If the foreign sales are effected at prices, which, though not monopolistic, yet yield normal profits when a proportionate share of the cost of production is debited against them, they are an obvious advantage to the monopolist. They yield a return themselves, and they also increase the return on the home production by enabling its cost to be reduced.

When they are effected at prices lower than this, they are still an advantage to the monopolist if their selling price does not fall below the average full cost of production which holds good when they are being produced, by more than the difference between this average full cost and that which would rule if they were not being produced, multiplied by the ratio of the quantity sold at home to that sold abroad.

(b) The power to "dump" surplus produce abroad, and so to realise on it without spoiling their regular market is also an advantage to the combinations which possess it, and would, pro tanto, encourage the investment of capital in them.

This matter of surplus dumping is, however, apt to be misconceived. When businesses have been established, and plant set up, it would always be an advantage, were it not for spoiling the market, to sell down to prime cost rather than not at all. $\mathrm{Mr}$. Jeans is, therefore, inverting the causal sequence when he writes : "Germans and Americans make great efforts to run full time, and in order to do this, they do not hesitate to sell their surplus

1 The Trusts and the Tariff, p. 167. 
in foreign markets at a very low figure." 1 It would generally be truer to say that by a tariff which checks re-imports, they are enabled in bad times safely to effect cheap sales abroad, and, in order to do this, they tend to work fuller time.

A. C. Pigod.

1 Ashley, British Industries, p. 22.

No. 53.--voL. XIV. 